\title{
Developing PSS Concepts from Traditional Product Sales Situation: The Use of Business Model Canvas
}

\author{
Johanna Wallin $^{1,2}$, Koteshwar Chirumalla ${ }^{1}$, Anthony Thompson ${ }^{3}$ \\ ${ }^{1}$ Division of Innovation and Design, Luleå University of Technology, Luleå, 97187, Sweden \\ ${ }^{2}$ GKN Aerospace Engine Systems, Trollhättan, 46181, Sweden \\ ${ }^{3}$ School of Engineering, Blekinge Institute of Technology, Karlskrona, 37136, Sweden \\ \{johanna.wallin, koteshwar.chirumalla\} altu.se \\ \{johanna.wallin\}@gknaerospace.com \\ \{anthony. thompson\} @bth. se
}

\begin{abstract}
In recent years there has been growing interest in utilizing a productservice system (PSS) approach when developing products and services in order to arrive at a business model focused on selling function or availability instead of physical products. However, the complex nature of PSS development has left many manufacturers still struggling to arrive at PSS concepts out of their traditional product sales situation in early design phases. The purpose of this paper is to propose an approach using the Business Model Canvas which could help manufacturers in the transition towards PSS development by articulating key business elements in developing and analyzing PSS concepts evolving from their traditional product sales situation. The paper presents preliminary findings from the aerospace industry and discusses the evolution of key business elements for PSS concepts from traditional product sales situation using the Business Model Canvas. Finally, the potential benefits of using the Business Model Canvas in a PSS context are discussed.
\end{abstract}

Keywords: Product-Service System, Business Model Canvas, Business Development, PSS design, Value Creation, Aerospace Industry.

\section{Introduction}

In recent years, many manufacturing firms are significantly generating major revenues in offering both products and services [1]. Hence, there has been growing interest in utilizing a product-service system (PSS) approach in developing products and services in order to arrive at a business model focused on selling function or availability instead of the physical product. Although adding services to their portfolios is not new (e.g. Levitt was writing about services from manufacturers in the 1970's [2]); what is relatively new is the shift from perceiving those services as a cost center to seeing them as part of a revenue-generating value proposition [3] [4]. Many researchers assert that PSS transition implies a major shift in the business operations, strategic thinking and management approaches that impacts the way products concepts are derived in the early phases [5] [6]. However, the complex nature of PSS development has left many manufacturers still struggling to design a PSS concept from their traditional sales situation in the earliest phases of product development [7]. Common ap- 
proaches to product design have kept product and service aspects separate, thus when either the product or the service dominates in a combined offer, the corresponding traditional product or service development approaches may be appropriate [8]. However, products and services that are tightly coupled must be designed in an integrated way [9]. With an underlying shift from business based on value from exchange of product ownership and responsibility toward business based on value through utility of the products/services [10], a fundamental reassessment of the core business is often necessary [11].

A substantial number of methods for PSS design appear in the literature; see Clayton et al. [8] for an evaluation of several of these methods as they relate to industrial practice. Clayton et al. [8] also note that there is some discrepancy regarding their case company's "articulate value proposition" phase and corresponding phases in the literature (e.g. "business case" and "client and suppliers business cases"). This suggests a need for a tool to support PSS-minded companies to identify and articulate the value proposition of the PSS they are designing.

Current research on PSS provides little guidance regarding the development of new business models for companies in the transition towards PSS development. Kindström [5] e.g. provides some insight into moving toward a service-based business model for manufacturing firms, but gives only minimal attention to PSS. One recent tool for developing new business models is "The Business Model Canvas" (here after referred as "BMC" in the text) [12] that can be used to systematically understand, design and implement a new business models. The reasons for choosing BMC for this study is that $\mathrm{BMC}$ is an intuitive and easy-to-use tool, covering different elements that have been identified as critical for a successful business model, providing an initial vision for companies that like to move towards PSS by viewing the business from a holistic standpoint. There has been little research conducted on using BMC for PSS design (e.g. [13-15]). This paper aims to fill this gap by answering the following research question: How can the Business Model Canvas support a company in developing PSS concepts in the early phases of the transition towards PSS development? This paper therefore proposes an approach using the BMC, which could help manufacturers in the transition towards PSS development by articulating the key business elements in developing and analyzing the PSS concepts (i.e. service/use-oriented PSSs) from their traditional sales situation (i.e. product-oriented PSS).

\section{Theoretical Framework}

\subsection{Product-Service System (PSS)}

In literature, researchers suggest different definitions and types of PSS based on their focus and perspective [1] [4] [8] [16]. For instance, Mont [17, p.71] defines PSS as: “...A system of products, services, supporting networks and infrastructure that is designed to be competitive, satisfy customer's needs and have a lower environmental impact than traditional business models". Tukker and Tischner [16] divide PSS concepts into three main categories-product-oriented, use-oriented, and result-oriented. The type of value embedded in the business offering (mainly product- or servicerelated) is chosen as the main criterion for this classification. A product-oriented PSS, 
in general, represents the traditional sale of a product embracing some additional services, such as maintenance, repair, warranty, upgrades, reuse and recycling. Useoriented PSS represents sale of the use or availability of a product to customers in different forms (e.g. leasing or sharing), but with the producer retaining ownership. The final category, result-oriented PSS, represents the sale of the result, function or capability of a product to customers, while retaining the ownership of the product. Three main categories of PSS are further elaborated and classified as eight types of PSS: product related service, product related advice/consultancy, product lease, product renting/sharing, product pooling, pay-per service unit, activity management, and functional result - depending upon the way value is created and offered to the customers [16]. Based on the extensive empirical data on 10,028 firms from 25 different countries, Neely [18] adds two new categories of PSS - integration-oriented and service-oriented - to the Tukker and Tischner classification. Integration-oriented PSS result when firms seek to add services by going downstream and vertically integrating (e.g. consulting services, financial services, retail and distribution, transportation and trucking services and property and real estate services) whereas service-oriented PSS result when firms incorporate services into the product itself (e.g. systems and solutions). Recently, Clayton et al. [8] present these five generic types of PSS within the product-service continuum to create a range of product-service offerings (Figure 1). Both models [8] [16] emphasize the continuum of PSS, but leave little guidance on how a company can place themselves on this continuum from a traditional situation.

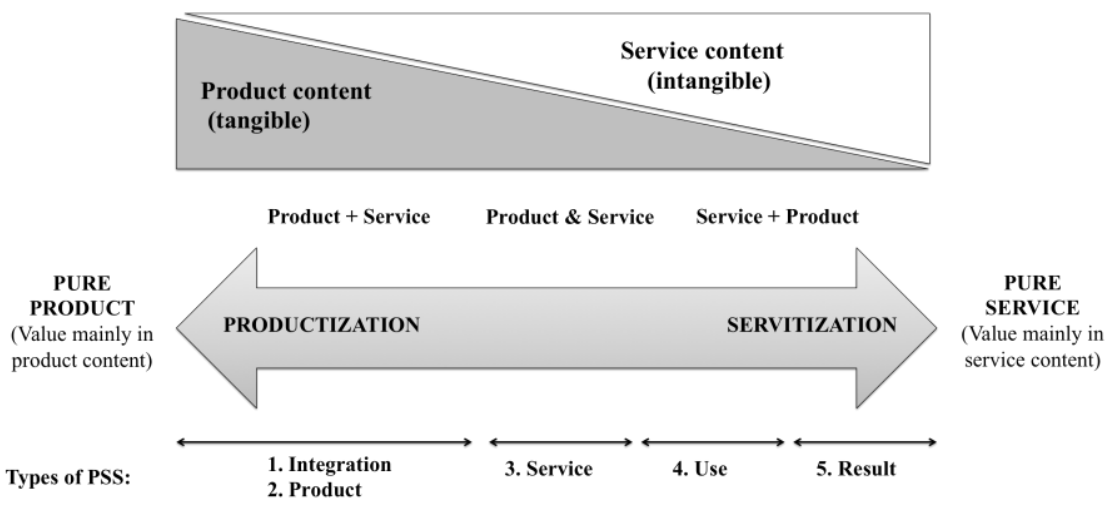

Fig. 1. Categorization of PSS types within the pure product-service continuum, adopted from Clayton et al [8] and Tukker and Tischner [16]

\subsection{PSS in the Aerospace Industry}

In the aerospace industry today, each aircraft engine is an opportunity to supply a stream of spare parts at high margins. Therefore the engines are often sold at reduced prices and the engine developers instead profit from maintenance and supply of spare parts, which typically represent product-oriented PSS business models [1]. There are also service-oriented PSS, where the engine is sold together with e.g. a monitoring system that keeps track of engine usage [19] and use-oriented PSS where the functionality of the engine is sold rather than the product itself, e.g. 'Power by the hour' or 
TotalCare ${ }^{\circledR}$ by Rolls Royce [20]. Commitment and availability is increasingly valued by the airlines, compared to the sale and purchase of the traditional product. Further, it is in the interest of the engine developer to control the risks that enable lowering ownership costs in order to enhance profitability for both parties [20].

\subsection{Business Modeling for PSS}

The shift towards a PSS offering alters the traditional view of value creation (e.g. [1], [16]). This triggers a transition from a 'transaction-based' to a 'long-term relationship-based' business connection [22], which necessitates redesigning the existing contractual and implicit relations and re-allocating risks and revenue structures. As a consequence, the successful implementation of a PSS solution needs to identify the supporting business models in order to address the organizational changes and operational strategies [21]. In this context, the business models that are traditionally product-based and short-term focused are not merely applicable [6]. A central virtue of the business model is that it takes into account different underlying business elements and puts them together to create a holistic and system-level picture of the business [12] [23]. Over the years, different authors have developed a number of business model frameworks with different underlying business elements. For instance, Chesbrough [24] uses six common business elements as a structuring and analytical frameworknamely, (1) articulate the value proposition, (2) identify a target market, (3) define the structure of the value chain required by the firm, (4) specify the revenue generation mechanism(s) for the firm, (5) describe the position of the firm within the value network, and (6) formulate the competitive strategy. Related to the PSS context, Spring and Araujo [21] summarize the four common business elements, including: (1) a concern with network structure; (2) a focus on how transactions are made; (3) revenue models and incentives, and (4) how providers' capabilities are transferred or accessed - through products, services or combinations thereof. Kujala et al. [6] propose a typology of five solution-specific business models and suggest that business models in a PSS context should be analyzed at the level of individual solutions depending upon the maturity of customers, instead of only at the firm- or business unit-level. A recent work by Lee et al. [13] proposes a structured methodology for business model design for a PSS that consists of a design template with which companies can analyze their current business models or invent new ones in a systematic manner. The template defines strategies and protocols for all business elements, which represent basic building blocks of the business model.

\subsection{The Business Model Canvas (BMC)}

In recent years business model innovation has become an important tool to organizations for rethinking their value creation process and identifying new ways of creating value for their customers and themselves (e.g. [6], [23]). The Business Model Canvas proposed by Osterwalder and Pigneur [12] is one such tool for describing, visualizing the existing business models or developing new ones in a shared language. The visual canvas describes the business model through nine basic business elements as shown in Table 1, which covers the four core areas of a business: customers, offer, infra- 
structure, and financial viability. Table 1 summarizes the details of each business element. Barquet et al. [14] present the characteristics of business model elements according to the type of PSS (i.e. mainly [16] classification) using BMC. Kim et al. [15] elaborate the work of Lee et al. [13] and present a case analysis of PSS design using the category of the BMC together with strategies and protocols.

Table 1. Key business elements in the Business Model Canvas [12]

\begin{tabular}{|c|c|}
\hline Business Elements & Description \\
\hline $\begin{array}{l}\text { Customer } \\
\text { Segments }\end{array}$ & $\begin{array}{l}\text {..defines the different groups of people or organizations an enterprise } \\
\text { aims to reach and serve. E.g., mass market, niche market, segmented, } \\
\text { diversified or multi-sided platforms. }\end{array}$ \\
\hline $\begin{array}{l}\text { Value } \\
\text { Propositions }\end{array}$ & $\begin{array}{l}\text {...describes the bundle of products and services that create value for a } \\
\text { specific } \text { customer segment. E.g., Newness, performance, design, price, } \\
\text { brand, cost/risk reduction, accessibility, or convenience/usability. }\end{array}$ \\
\hline Channels & $\begin{array}{l}\text {...describes how a company communicates with and reaches it's cus- } \\
\text { tomer segments to deliver a value proposition. E.g., sales force, web } \\
\text { sales, own stores, partner stores, or wholesaler. }\end{array}$ \\
\hline $\begin{array}{l}\text { Customer } \\
\text { Relationships }\end{array}$ & $\begin{array}{l}\text {...describes the types of relationships a company establishes with } \\
\text { specific customer segments. E.g., dedicated personal assistance, self- } \\
\text { service, automated services, communities, or co-creation. }\end{array}$ \\
\hline Revenue Streams & $\begin{array}{l}\text {...represents the cash a company generates from each customer seg- } \\
\text { ment. E.g., asset sale, usage fee, subscription fees, lend- } \\
\text { ing/renting/leasing, licensing, brokerage fees, or advertising. }\end{array}$ \\
\hline $\begin{array}{l}\text { Key } \\
\text { Resources }\end{array}$ & $\begin{array}{l}\text {...describes the most important assets required to make a business } \\
\text { model work. E.g., physical, intellectual, human, or financial. }\end{array}$ \\
\hline Key Activities & $\begin{array}{l}\text {...describes the most important things a company must do to make it's } \\
\text { business model work. E.g., production, or platform/network. }\end{array}$ \\
\hline $\begin{array}{l}\text { Key } \\
\text { Partnerships }\end{array}$ & $\begin{array}{l}\text {...describes the network of suppliers and partners that make the busi- } \\
\text { ness model work. E.g., strategic alliances, or joint ventures. }\end{array}$ \\
\hline Cost Structure & $\begin{array}{l}\text {... describes all costs incurred to operate a business model. E.g., cost- } \\
\text { driven, value-driven, fixed costs, or variable costs. }\end{array}$ \\
\hline
\end{tabular}

\section{Methodology}

This paper is based on a case study with a company that is an engine component and subsystem developer in the aerospace industry with a strong focus on traditional product development and additional maintenance services. The company has recently been transforming towards a PSS provider. On the military business side where the company is an engine OEM (Original Equipment Manufacturer), it has come far in service integration to the product offers and provides complete product-service systems. On the commercial business side where the company is a component developer, which requires close collaboration with the OEM, the company has recently increased the solution-based offers. This collaboration with the OEMs is described as a risk and revenue sharing partnership, where the partners shares development cost, risk and 
revenue throughout the engine program, which it is not in a ordinary customersupplier relationship. Since the company is undergoing the transition towards PSS development, it is hence an ideal case for the purpose of this paper. Data has been collected through observations at the company and ten semi-structured interviews with stakeholders in PSS development and business development, which include engineers, project managers, process owners, business developers, and company specialists, where some also have used the BMC in their work. The data has been analyzed using a pattern matching technique to find coinciding (and non-coinciding) patterns [25]. The BMC has been used to summarize the data, deriving the key business elements to the PSS concepts from the traditional product sales situation. Furthermore, BMC elements have been used as a guiding tool for interviews.

\section{Business Model Canvas for PSS Concepts: Empirical Findings}

One of the main challenges to transition into PSS development is the creation of new business models. As a component developer the business case is dependent on the business case of the OEM. It is easier to imagine service integration in products as an OEM. Hence, methods to support PSS development are even more important for component developers: "We cannot control the market, only how we do things, how we would like to do business", described an interviewee. The company uses the term "soft products" to describe their servitization journey. Soft products represent all products and services sold to a customer that enhance the customer's experience and satisfaction other than the sale of new products, such as fleet management, product support and monitoring systems. While talking about his perception on PSS, one of the process owners said "I would like to see our expansion of the area in soft products in the perspective of services, related to more efficient collaboration /.../ That says it is not necessarily part of the product portfolio. But that is part of our brand. That says we are the most easy to work with".

Even though the company has developed traditional services such as maintenance and product support, the transition towards servitization has involved creation of software that tracks life consumption of the engine components, which was an unknown area for the company and involved risks. One challenge with entering unknown business areas is seeing the potential of new opportunities. The Business Model Canvas, in this context, is used to understand the potential benefits and challenges of entering unknown business areas as well as exploring related business elements around the unknown business area. At the case company the BMC is not a wellknown tool, but it has been used in some groups for business development and PSS development groups. The tool has been used both as a workshop tool, where the group has performed a brainstorm activity for each section, as well as by individuals building a business case. The following paragraphs discuss each element of the BMC in detail. From the empirical discussion, Table 2 summarizes the evolution of business model elements for PSS concepts from the traditional product sales situation. 
Customer Segments: As an engine component developer, the main customer is the engine OEM. However, this collaboration can be described as a risk and revenue sharing partnership rather than a customer-supplier relationship. In PSS development the company has the possibility to look further down the supply chain for potential customers. "[The airlines] could be a customer. That scenario is also possible". But reaching for customers segments further down the supply chain, such as aircraft manufacturer or airlines would be strengthened if made in partnership with OEM.

Value Proposition: In a traditional sales situation, value is primarily exchanged through the component itself. "It's about making it clear what functions you are fulfilling with the product", described a specialist. Another interviewee described the organizational culture as adding value: "I think we are appreciated for our Swedish way, if we say something, that is the way it is, sincerity and loyalty". One of the project informants described the technology development as adding value: "What technology can we bring to the table?; that is our value, in addition to the product development". It is the same thing with the add-on maintenance service. In PSS business models, the value of the component is related more to the component in context, i.e. the value of the whole system: "But the value the product generates is, of course, the same but we can add value in the form of services, since we are further into the process". Value is added through add-on services for increased product functionality, reduced risk, increased safety, and reduced cost. Being a partner and not only a supplier could be considered as a service since it involves e.g. the sharing of risk and perhaps other value-added activities: "We might be offering services today that we do not know that we are offering". Another interviewee added "Service can also be the proactive way of living from [the company] side when we working with the OEMs regarding how we can improve our engineering support and how we can improve development methods in the prospective way of learning and feedback [those in] to the organization. That's the service that comes back internally as well as together with the OEM".

Channels: The engine components are developed in close collaboration with the engine OEM. And the engine programs are one of the main channels with the OEM customer. One interviewee commented on this close collaboration: "Our main distribution channel considering our value proposition is through product development (PD) projects. We also have business contacts and other channels and yes they're important too, but I think if you talk about building value and being a cog in the wheel, the PD projects are the most important thing, since we have straight communication [in PD projects]". As the company transitions further along its PSS journey, other partnerships such as joint ventures could be possible in the future.

Customer Relationships: The company has strong ties with the closest customers (engine OEM for products, airlines for services). There are also (perhaps weaker) ties to other stakeholders in the industry. In PSS development, relationships become even more important, especially with partners in extended collaborations. Ties are strengthened with both upstream and downstream actors who are affected by the PSS, including aircraft manufacturer, process technology suppliers, service centers, engine 
OEMs partner companies, and engine OEM competitors (e.g. [22]). One experienced informant pointed out that, "We work collaboratively early, we want to be even earlier, of course, to have a better plan. Let's say collaborating even earlier with the engine OEMs, aircraft OEMs, and systems OEMs would enable us to be better prepared from a technology prospective but also time-wise".

Revenue Streams: In the engine programs, revenue comes from selling the engine and, perhaps more importantly, the selling of spare parts: "The company makes money on selling spare parts. If those revenues are decreased we are forced to think of other ways to make money", described a project manager. But as a component developer the revenue streams are dependent on the business case of the OEM. "When the OEM sold 'power by the hour' to their customers, they had no incentives to sell spare parts anymore", the same incentives are therefore needed in the whole value chain "everyone would think of long product life, everyone would think of low lifecycle cost" said a project manager. In a PSS situation there is also a possibility to increase revenue through availability contracts and selling of licensees.

Key Resources: In the traditional sales situation the key resources are related to the structure of product development and the supply chain; the competences and knowledge of the product; and the production. Including service aspects in the product design space elevates the need to integrate an extended set of new competencies from many actors within the network, i.e. cross-functional cooperation: "This business of system development, we have included many consultants" said one interviewee. Another interviewee added: "We simply had to bring in many consultants since there were no such resources at the company". Some consultants later became employees in order to keep the competence within the organization.

Key activities: In traditional concepts product and service development activities are distinct. In this case, key activities involve e.g. assigning the positions that are responsible for development of the product. Key activities also involve infusing trust to the customer: "We need to infuse trust to create value for the customer, come up with ideas, be proactive, show how we work and develop our methods". In PSS concepts the products and services are co-developed in an integrated way to reduce risks, increase safety and reduce cost. The PSS concept can include activities such as calculating life consumption of the component and monitoring the environment where the product is used. PSS can also involve increased external collaboration: "We know our application. So it is all about going out there and trying to find those pieces of puzzle that you need. We need to go outside our door, because if you only sit in your little team internally... of course you could come up with the world's best solution but the probability is quite low. If you constantly work with the world around you the probability is much greater," described a project manager.

Key Partnerships: Key partners in traditional sales situations are the customer and suppliers in the aerospace industry. The company also has close collaboration with academia: "We have a network of lots of customers that we work with, loads of suppliers that we interact with, a great number of universities and professors" described 
an interviewee. In a PSS concept the partnerships may be even broader; here they can also include extended value chain actors as well as IT suppliers, e.g. because of the increased software development. However "To handle and channel data that is not in our value proposition" described an interviewee and therefore such a partner could be needed. "But to establish the system infrastructure, I think that's our value proposition".

Table 2. Evolution of business model elements for PSS concepts from traditional situation

\begin{tabular}{|c|c|c|}
\hline $\begin{array}{l}\text { Business Model } \\
\text { Canvas Ele- } \\
\text { ments }\end{array}$ & $\begin{array}{l}\text { Traditional product sales situation } \\
\text { (product-oriented) }\end{array}$ & $\begin{array}{l}\text { PSS concepts (service- } \\
\text { oriented/ use-oriented) }\end{array}$ \\
\hline $\begin{array}{l}\text { Customer } \\
\text { Segments }\end{array}$ & $\begin{array}{l}\text { Engine OEM of the product supply } \\
\text { chain in aerospace industry }\end{array}$ & $\begin{array}{l}\text { Potentially new customers in } \\
\text { aerospace industry. E.g. air- } \\
\text { lines, aircraft manufacturers. }\end{array}$ \\
\hline $\begin{array}{l}\text { Value Proposi- } \\
\text { tion }\end{array}$ & $\begin{array}{l}\text {-The value of the product functionali- } \\
\text { ty and light weight technology } \\
\text {-The value of the add-on services for } \\
\text { product functionality }\end{array}$ & $\begin{array}{l}\text { Added value from the com- } \\
\text { ponent contribution to overall } \\
\text { system performance service; } \\
\text { value of risk reduction, safety } \\
\text { increase, and cost reduction }\end{array}$ \\
\hline Channels & Partner programs & $\begin{array}{l}\text { Partner programs or Joint } \\
\text { venture }\end{array}$ \\
\hline $\begin{array}{l}\text { Customer } \\
\text { Relationship }\end{array}$ & $\begin{array}{l}\text { Strong ties to closest customer (En- } \\
\text { gine OEM for products, airlines for } \\
\text { services) and weak ties to other } \\
\text { stakeholders in the network }\end{array}$ & $\begin{array}{l}\text {-Strong ties to various stake- } \\
\text { holders within the industry } \\
\text { who are affected by the func- } \\
\text { tionality of the product; Dedi- } \\
\text { cated technical assistance and } \\
\text { co-creation in early phases }\end{array}$ \\
\hline Revenue Streams & $\begin{array}{l}\text {-Percentage of engine revenue } \\
\text {-Service contracts } \\
\text { - Revenue on spare parts sales }\end{array}$ & $\begin{array}{l}\text { Integrated product-service } \\
\text { contracts, availability con- } \\
\text { tracts and licensees }\end{array}$ \\
\hline Key Resources & $\begin{array}{l}\text {-Product and production knowledge } \\
\text {-Patents } \\
\text {-Financial } \\
\text {-Contracts }\end{array}$ & $\begin{array}{l}\text { Added key resources: } \\
\text {-Cross-functional knowledge } \\
\text {-Relationships with extended } \\
\text { collaborators }\end{array}$ \\
\hline Key Activities & $\begin{array}{l}\text {-Development \& manufacturing of } \\
\text { product } \\
\text {-Service development \& provision } \\
\text {-Assign responsible positions }\end{array}$ & $\begin{array}{l}\text {-Integrated product-service } \\
\text { system development; Calcu- } \\
\text { lating life consumption; Mon- } \\
\text { itoring product environment }\end{array}$ \\
\hline Key Partnerships & $\begin{array}{l}\text {-Customer and suppliers in the aero- } \\
\text { space industry } \\
\text {-Academia }\end{array}$ & $\begin{array}{l}\text { Extended stakeholder network } \\
\text { through joint ventures, e.g. IT } \\
\text { partners, service centers. }\end{array}$ \\
\hline Cost Structures & $\begin{array}{l}\text { Development; Material and produc- } \\
\text { tion; Service provision; Entrance fee } \\
\text { in the engine programs }\end{array}$ & $\begin{array}{l}\text { Added cost of ensuring up- } \\
\text { time, software development, } \\
\text { monitoring costs and IT de- } \\
\text { livery. }\end{array}$ \\
\hline
\end{tabular}

Cost Structure: Costs in the traditional sales situations include product development, production, material and costs for maintenance services. In PSS situations the cost 
structure is not much different, but there could be added cost related to e.g. ensuring uptime, assuming additional risks, software development and monitoring costs. One interviewee described the additional costs of a monitoring system: "When it is up and running then it's the infrastructure, servers and software, to keep it configured and updated so to speak".

\section{$5 \quad$ Discussion and concluding remarks}

With the unprecedented speed at which customers' needs and behaviors are changing, a company's ability to rapidly adapt or generate innovative business models is critical to success. This study found that Business Model Canvas is a promising tool-with their intuitive and easy-to-use nature - for the companies to rapidly analyze and discuss their traditional product sales situation according to the nine business elements, thereby deriving the PSS concepts in the early phases. By having a value proposition as a central position, BMC provides an overall view of "what" and "how" the business would look like in the transition towards PSS development. Since PSS not only involves different organizational areas within the development organization but can also affect several organizational areas for the customer, this can challenge the marketing of the system and increases the importance of visualizing the value proposition in the business model. One interviewee described this challenge: "The value is there. No doubt about that. The question is how to sell it ... To be able to sell it [the PSS] you must find the economical buyer in each company, thus the person that can see the value. If you go through the traditional entrance, where you sell your product, perhaps the purchasing organization, they might close the door in front of you".

The case company has realized the benefits of its PSS journey. As a company specialist put it: "I think that the servitization, that is a trend that will last". However, the challenge for manufacturers is to "take a mental break" from their product when exploring how to develop a PSS. History and attachment to the product may make it difficult for the company to see radical innovation opportunities that may or may not require significant changes to their core product. The BMC, with its initial emphasis on the value proposition, may aid companies in taking that mental break from their product and get a "PSS mindset". Furthermore, the BMC, through its structure, guides them in the next steps to help understand how to take the value proposition and build a business model around it, eventually linking back to the company's core product while adding significant context to the value offered by the product. By providing a level of abstraction related to the various business elements through qualitative assessment, the BMC can help the company's strategic plan (i.e. by defining overall mission and strategic goals) on an individual solution level [6] at a conceptual phase even before commencing business operations. Additionally, the BMC is a visual tool that is easy to use by both individuals and groups. One user described it: "It is very fast. You get quickly into the business model. It is good to visualize the big picture, so to speak". However, even though the users at the case company like it, one critical point was brought up by PSS developer: "It doesn't bring up risks. But we added that, business risks". 
This study suggests that the BMC is a promising tool to support modifying or creating new business models at a faster pace. But as a tool to support the transition towards PSS development, it needs to have a clearer focus on this change, and some modifications should therefore be added. First is the modification of questions in the BMC to emphasize a change in perspective and to widen the business scope. For example, instead of only asking: What value do we deliver to the customer? and For whom are we creating value? We should also ask: Are there additional customer needs that we could be satisfying? and Who could be benefitting from the value we are creating? Second is the addition of business risks, since the transition towards PSS development involves taking new risks. This could either be done by adding a new element of Business Risks to the BMC or with additional risk questions in each of the nine existing business elements. For instance, the questions such as: What are our principal business risks in PSS transition? How do we integrate risks with the company's strategic direction? How effective is our process for managing risks?

This study evaluated the use of the Business Model Canvas in developing PSS concepts especially with respect to manufacturing companies seeking to transition towards PSS. The paper provides the empirical basis in using BMC for an aerospace, business-to-business (B2B) context. This is especially important since the current PSS literature on BMC usage is mostly focused on business-to-consumer (B2C) situations. Moreover, a majority of PSS literature focuses on specific issues of PSS development separately such as cost, contracts, knowledge management, supply chain relationships etc. These issues may fall into one or two elements of business elements, which make it difficult for the companies to obtain a complete holistic view of the business challenges in PSS transition. BMC provides a visual platform for companies, which could allow them to consider all development issues related to various business elements very early in the process, thereby guiding them to develop a profitable PSS business model with effective strategic actions.

Acknowledgments. The authors would like to acknowledge the case company GKN Aerospace Sweden AB, which allowed the authors to conduct this research. Further, the authors wish to extend the gratitude to the participants and teaching staff in the "PV18 Product-Service Systems" doctoral course at Luleå University of Technology and Blekinge Institute of Technology during 2011-2012.

\section{References}

1. Meier, H., Roy, R., Seliger, G.: Industrial Product-Service Systems-IPS ${ }^{2}$. CIRP AnnalsManufacturing Technology, 59, 607-627 (2010)

2. Levitt, T.: Production-line approach to service. Harvard Business Review. 50(5), 41-52 (1972)

3. Wise, R., Baumgartner, P.: Go Downstream: the New Profit Imperative in Manufacturing. Harvard Business Review, 77(5), 133-141 (1999)

4. Wang, P.P., Ming, X.G., Li. D., Kong, F.B., Wang, L. and Wu, Z.Y.: Status review and research strategies on product-service systems. J. Production Research, 49 (22), 6863-6883 (2011) 
5. Kindström, D. Towards a service-based business model - Key aspects for future competitive advantage. European Management Journal, 28(6), 479-490 (2010)

6. Kujala, S., Artto, K., Aaltonen, P., Turkulainen, V.: Business models in project-based firms - towards a typology of solution-specific business models. Int. J. Project Management, 28(2), 96-106 (2009)

7. Isaksson, O., Larsson, T.C., Rönnbäck, A.Ö.: Development of product-service systems: challenges and opportunities for the manufacturing firm. J. Engineering Design, 20(4), 329-348 (2009)

8. Clayton, R.J., Backhouse, C.J., Dani, S.: Evaluating existing approaches to product-service system design: A comparison with industrial practice. J. Manufacturing Technology Management, 23(3), 272-298 (2012)

9. Cavalieri, S. and Pezzotta, G.: Product-Service Systems Engineering: State of the art and research challenges. Computers in Industry, 63, 278-288 (2012)

10. Tan, A.R., McAloone, T.C.: Characteristics of strategies in product/service system development. In: $9^{\text {th }}$ International Design Conference, Dubrovnik, pp. 1435-1442 (2006)

11. Sakao, T., McAloone, T.C.: Product with Service, Technology with Business Model: Expanding Engineering Design. In: $18^{\text {th }}$ International Conference on Engineering Design, Copenhagen, Vol. 4, pp. 449-460 (2011)

12. Osterwalder, A. Pigneur, Y.: Business Model Generation. NJ: John Wiley. (2010)

13. Lee, J.H., Shin, D.I., Hong, Y.S., Kim, Y.S.: Business Model Design Methodology for Innovative Product-Service Systems: A Strategic and Structured Approach. In: $18^{\text {th }}$ International Conference on Engineering Design, Copenhagen, Vol. 3, pp. 221-232 (2011)

14. Barquet, A.P.B., Cunha, V.P., Oliveira, M.G., Rozenfeld, H.: Business Model Elements for Product-Service System. In: $3^{\text {rd }}$ CIRP International Conference on Industrial ProductService Systems, Braunschweig, pp. 332-337 (2011)

15. Kim, Y.S., Lee, S.W., Kim, J.H., Do, S.H..: A Design Case of Product-Service SystemsUrban umbrella rental PSS. In: $12^{\text {th }}$ International Design Conference, Dubrovnik, pp. 213222 (2012)

16. Tukker, A., Tischner, U.: New Business for Old Europe: Product-Service Development, Competitiveness and Sustainability. Sheffield: Greenleaf Publishing Ltd, (2006)

17. Mont, O.: Product-Service Systems: Panacea or Myth? PhD Thesis, Lund University, 2004: 140, (2004)

18. Neely, A.: Exploring the financial consequences of the servitization of manufacturing. Operations Management Research, 1(2), 103-118, (2008)

19. Ward, Y., Graves, A.: Through-life management: The provision of total customer solutions in the aerospace industry. J. Services Technology Management, 8(6), 455-477 (2007)

20. Harrison, A.: Design for service - Harmonising product design with a services strategy. The ASME Turbo Expo 2006, 6-11 May, Barcelona, Vol. 2, pp. 135-143, (2006)

21. Spring, M., Araujo, L.: Service, services and products: rethinking operations strategy. Int. J. Operations \& Production Management, 29(5), 444 - 467 (2009)

22. Chirumalla, K., Bertoni, A., Ericson, A., Isaksson, O.: Knowledge-Sharing Network for Product-Service System Development: Is it atypical? In: $4^{\text {th }}$ CIRP International Conference on Industrial Product-Service Systems, Japan, pp. 109-114 (2012)

23. Zott, C., Amit, R., Massa, L.: The Business Model: Recent Developments and Future Research. J. Management, 37 (4), 1019-1042 (2011)

24. Chesbrough, H.: Business model innovation: It's not just about technology anymore. Strategy and Leadership, 35(6),12-17 (2007)

25. Yin, R.K.: Case Study Research: Design and Methods. CA: Sage Publications, (2009) 